\title{
ANALISIS PENGARUH PENGEMBANGAN KARIER TERHADAP KINERJA PADA KANTOR KESATUAN BANGSA DAN POLITIK KABUPATEN LAMPUNG BARAT
}

\author{
Helly Pertiwi ${ }^{(1)}$, Ahiruddin ${ }^{(2)}$, Sodirin ${ }^{(3)}$ \\ Fakultas Ekonomi Universitas Sang Bumi Ruwa Jurai \\ helly_pertiwi@gmail.com,ahiruddin@fe.saburai.ac.id,sodirin@fe.saburai.ac.id
}

\begin{abstract}
Abstrak. Dinas Kesatuan Bangsa dan Politik Kabupaten Lampung Barat mempunyai tugas menyiapkan bahan dalam rangka membantu melaksanakan penjabaran kebijakan teknis di bidang kesatuan bangsa. Program pengembangan karier memberikan kesempatan kepada pegawai untuk menyelidiki minat, kebutuhan. dan pilihan karier dalam organisasi. Melalui pengembangan karier pegawai dibantu untuk mengembangkan kecakapan dan kemampuan yang diperlukan sasaran jabatan. Tujuan penelitian ini adalah untuk mengetahui Pengaruh Pengembangan karier Terhadap Kinerja Kantor Kesatuan Bangsa Dan Politik Kabupaten Lampung Barat. Hasil pengujian bahwa nilai $R$ square sebesar 0.670. Nilai $R$ square ini menunjukkan bahwa besarnya kontribusi variabel independen terhadap variabel dependen adalah sebesar $67,0 \%$. Nilai signifikansi sebesar 0.00 lebih kecil dari 0.05 , dengan demikian persamaan model ini bersifat fit atau layak digunakan. Pengujian hipotesis yang menyatakan "Pengembangan karir berpengaruh terhadap kinerja." Pengujian dilakukan dengan menggunakan uji t yang menunjukkan bahwa Pengembangan karir berpengaruh terhadap kinerja. Pengujian dilakukan dengan menggunakan uji t pada tingkat keyakinan signifikansi $\alpha 0.05$. Dari hasil tabel 4.8 dapat diketahui bahwa tingkat signifikansi sebesar $0.00<0.05$ dengan nilai $t_{\text {hitung }}>\mathrm{t}_{\text {tabel }}$ yaitu $8.063>2.034$, dengan demikian hipotesis diterima yang berarti Pengembangan karir berpengaruh terhadap kinerja.
\end{abstract}

Kata kunci: Karier, Kinerja, Pengaruh, Pengembangan.

\section{PENDAHULUAN}

Pelaksanaan tugas dan pekerjaan merupakan suatu kewajiban bagi para anggota dalam suatu organisasi, baik dalam organisasi pemerintah maupun non pemerintah. Dalam pelaksanaan tugas dan kewajiban tersebut terdapat suatu tujuan yang sama yakni mengharapkan suatu hasil yang baik serta memuaskan sesuai dengan apa yang telah ditentukan sebelumnya. Untuk mendapatkan suatu hasil kerja yang baik sesuai dengan tujuan, maka setiap organisasi mempunyai suatu aturan yang dituangkan dalam bentuk kebijakan. Kebijakan ini dibuat dengan maksud agar tiap komponen organisasi melaksanakan tugas sesuai dengan tujuan yang ditetapkan.

Hakekat pemerintah adalah pelayanan kepada masyarakat. Pemerintah tidaklah diadakan untuk melayani dirinya sendiri, melaikan untuk melayani rakyat dengan kata lain pemerintah adalah pelayan masyarakat. Menurut pendapat Kurniawan (2005) "Pelayanan publik oleh birokrasi merupakan salah satu perwujudan dari fungsi aparatur Negara sebagai abdi masyarakat disamping sebagai abdi Negara".

Pegawai negeri sipil merupakan Sumber Daya Aparatur Negara yang bertugas memberikan pelayanan masyarakat secara profesional, jujur, adil dan merata dalam penyelenggaraan tugas Negara, pemerintah dan pembangunan yang dilandasi kesetiaan dan ketaatan kepada pancasila dan undang-undang dasar 1945. Kedudukan dan peranan pegawai negeri sipil di Indonesia dirasakan semakin penting untuk menyelenggarakan 
pemerintahan dan pembangunan dalam usaha mencapai tujuan nasional yaitu mewujudkan masyarakat madani yang taat hukum, beradapan moderen, demokratis, makmur, adil dan bermoral tinggi.

Dinas Kesatuan Bangsa dan Politik Kabupaten Lampung Barat mempunyai tugas menyiapkan bahan dalam rangka membantu melaksanakan penjabaran kebijakan teknis di bidang kesatuan bangsa. Untuk menyelenggarakan tugas sebagaimana dimaksud pada Kesatuan Bangsa dan Politik mempunyai fungsi: Penyiapan bahan rumusan kebijakan teknis di bidang kesatuan bangsa; Perencanaan dan pelaksanaan kegiatan di bidang kesatuan bangsa; Penyiapan bahan penyelenggaraan kegiatan di bidang kesatuan bangsa; dan Pelaksanaan monitoring, evaluasi dan pelaporan kegiatan di bidang kesatuan bangsa

Dinas Kesatuan Bangsa dan Politik Kabupaten Lampung Barat menerapkan pokok-pokok untuk memajukan Manajemen Sumber Daya Manusia dengan menerapkan suatu sistem reward and punishment. Reward diberikan kepada pegawai yang melakukan prestasi lebih atau menciptakan inovasi-inovasi dalam pekerjaannya. Sedangkan punishment diberikan kepada pegawai-pegawai yang melakukan penyimpangan atau pelanggaran dalam pekerjaannya,

akan tetapi pengembangan karier pegawai belum didasarkan pada pola produktivitas kerja para pegawai, sehingga para pegawai kurang obyektif dalam bertanggung jawab terhadap pekerjaannya dikarenakan kurangnya promosi dan rencana karier pegawai terhadap pekerjaan yang telah menjadi tanggung jawabnya.

Program pengembangan karier memberikan kesempatan kepada pegawai untuk menyelidiki minat, kebutuhan. dan pilihan karier dalam organisasi. Melalui pengembangan karier pegawai dibantu untuk mengembangkan kecakapan dan kemampuan yang diperlukan sasaran jabatan.

Keterkaitan antara pengembangan karier dengan tingkat produktivitas kerja perlu diperhatikan oleh pihak perusahaan. Peranan Pengembangan karier perusahaan yang baik dan berjalan efektif akan menghasilkan karyawan yang termotivasi untuk menghasilkan produktivitas kinerja lebih tinggi.

Demikian juga dengan Dinas Kesatuan Bangsa dan Politik Kabupaten Lampung Barat. Pentingnya Pegawai agar selalu meningkatkan kinerja. Oleh karena itu Dinas Kesatuan Bangsa dan Politik Kabupaten Lampung Barat selalu berusaha untuk mempertahankan pegawai yang berprestasi agar tetap setia. Melalui kinerja, dapat diketahui berapa jumlah pegawai yang berprestasi sehingga dapat diambil keputusan mengenai pelaksanaan pengembangan karier pegawai pada Dinas Kesatuan Bangsa dan Politik Kabupaten Lampung Barat. .

Kinerja yang tinggi bagi pegawai sangat diperlukan dalam setiap usaha mencapai tujuan organisasi. Sebaliknya dengan kinerja yang rendah akan sukar untuk bagi instansi/satker untuk mencapai hasil kerja yang maksimal.

Oleh karena itu hal-hal yang terkait dengan tugas pokok dan fungsi yang harus dijalankan pegawai perlu didukung dengan pengembangan karier sehingga konsisten dalam melaksanakan pekerjaannya. Selain itu perlu juga diberi kebebasan untuk mengembangkan kemampuannya dan juga perlu diberi kesempatan untuk pengembangan karir dan berhak atas kompensasi yang layak dan sesuai dengan produktivitas kerja yang dicapainya.

Sebagai suatu organisasi dengan struktur organisasi yang jelas tentu saja menyimpan berbagai macam permasalahan diantaranya yang berkaitan dengan kesiapan Sumber Daya Manusia (SDM)nya untuk menempati suatu jabatan. 
Rencana Pengembangan karier merupakan faktor yang sangat berperan dalam menentukan tingkat produktivitas kerja seorang PNS khususnya Pegawai Negeri Sipil (PNS) pada Dinas Kesatuan Bangsa dan Politik Kabupaten Lampung Barat. Untuk itulah, kiranya perlu merumuskan secara rinci dan terpadu usaha-usaha yang harus dilakukan untuk mencapai produktivitas pegawai yang ada dalam organisasi Dinas Kesatuan Bangsa dan Politik Kabupaten Lampung Barat. .

Dengan mengetahui besarnya pengaruh dari promosi dan rencana pengembangan karier, maka para pimpinan dan pihakpihak terkait di lingkungan Dinas Kesatuan Bangsa dan Politik Kabupaten Lampung Barat akan mudah dalam melakukan langkah-langkah pembinaannya.

Belum ada secara rinci dan terpadu usaha-usaha yang harus dilakukan untuk mencapai kinerja pegawai yang ada dalam Dinas Kesatuan Bangsa dan Politik Kabupaten Lampung Barat.. dengan mengetahui besarnya pengaruh pengembangan karier maka pihak-pihak terkait di lingkungan Dinas Kesatuan Bangsa dan Politik Kabupaten Lampung Barat akan mudah dalam melakukan langkah-langkah pengembangan pegawainya.

Dari uraian tersebut maka peneliti tertarik untuk melakukan peneliti dengan judul: "Analisis Pengaruh Pengembangan Karier Terhadap Kinerja Pada Kantor Kesatuan Bangsa Dan Politik Kabupaten Lampung Barat".

\section{KAJIAN TEORI}

\section{Pengertian Manajemen}

Manajemen adalah suatu proses, seni dan ilmu dalam rangka perencanaan pengorganisasian, penyusunan, pengarahan, pengelolahan sumber daya secara efisien untuk mencapai tujuan yang telah ditetapkan.

Menurut Panggabean (2008:13), manajemen adalah sebuah proses yang terdiri atas fungsi-fungsi perencanaan, pengorganisasian, kepemimpinan, dan pengendalian kegiatan sumber daya manusia dan sumber daya lainnya untuk mencapai tujuan yang telah ditetapkan secara efisien. Definisi-definisi manajemen diatas mengandung beberapa pengertian:

1. Manajemen adalah suatu proses, yaitu proses yang dilaksanakan dan diawasi untuk mecapai tujuan.

2. Manajemen mengandung tujuan yang dicapai melalui tindakan-tindakan perencanaan pengorganisasian, penyusunan, kepemimpinan, dan pengawasan yang disebut fungsi manajemen.

3. Manajemen merupakan suatu penggabungan orang-orang yang melakukan kegiatan atau keaktivan manajemen dalam suatu badan tertentu.

4. Manajemen adalah suatu seni dan ilmu, yaitu kemampuan dan keterampilan pribadi. Manajemen sebagai ilmu berfungsi menerangkan gejala-gejaladan kejadian-kejadian, sedangkan manajemen sebagai seni berfungsi untuk mencapai tujuan yang nyata dan mendatangkan manfaat.

\section{Pengembangan Karier}

Pengembangan karir (seperti promosi) sangat diharapkan oleh setiap pegawai. Dalam praktek pengembangan karir lebih merupakan suatu pelaksanaan perencanaan karir seperti yang diungkapkan oleh Handoko (2000), bahwa pengembangan karir adalah peningkatan-peningkatan pribadi yang dilakukan seseorang untuk mencapai suatu rencana karir. 
Menurut Simamora (1995), proses
pengembangan karir dalam suatu
pendekatan formal yang diambil organisasi
untuk memastikan bahwa orang-orang
dengan kualifikasi dan pengalaman yang
tepat tersedia pada saat dibutuhkan. Sehingga pengembangan karir dapat dikatakan suatu kondisi yang menunjukkan adanya peningkatan-peningkatan status seseorang dalam organisasi dalam jaluir karir yang telah ditetapkan.

Pengembangan karir yang dilaksanakan dan dikembangkan pada SDM aparatur (PNS) melalui pembinaan karir dan penilaian sistem prestasi kerja. Sistem karir pada umumnya melalui kenaikan pangkat, mutasi jabatan serta promosi (pengangkatan ke jabatan lain). Lebih lanjut Moekijat (1995) mengatakan bahwa : dalam pengembangan karir seharusnya diterima bukan sekedar promosi ke jabatan yang lebih tinggi, tetapi sukses karir yang dmaksudkan seorang karyawan mengalami kemajuan dalam bekerja, berupa kepuasan dalam jabatan yang dipercayakan serta meningkatkan ketrampilan.

Hal yang penting dalam pengembangan karir adalah: (1) ada kesempatan untuk melakukan yang menyenangkan;

Kesempatan untuk mencapai sesuatu yang berharga; (3) Kesempatan untuk mempelajari hal-hal yang baru; (4) kesempatan untuk mengembangkan kecakapan kemampuan.

Pengembangan karir melalui promosi (promotion) bagi PNS merupa kan suatu yang sangat diidamkan dam merupakan tujuan perencanaan karir. Promosi adalah perpindahan yang memperbesar authority dan responsibility karyawan ke jabatan yang lebih tinggi di dalam suatu organisasi, sehingga kewajiban, hak, status, dan penghasilan semakin besar (Malayu, 2000). Dengan promosi berarti ada kepercayaan dan pengakuan mengenai kemampuan serta kecakapan pegawai untuk menduduki jabatan yang lebih tinggi.

Menurut Flippo (1995), promosi berarti perpindahan dari suatu jabatan ke jabatan lain yang mempunyai status dan tanggung jawab yang lebih tinggi. Biasanya perpindahan jabatan yang lebih tinggi disertai dengan peningkatan gaji/ upah lainnya.Terkait dengan pengembangan karir PNS, model pengembangan karir yang mendasarkan pada Peraturan Pemerintah No. 100 tahun 2000 Tentang Pengangkatan PNS dalam Jabatan Struktural. Mencakup : (1) Pendidikan : pendidikan dasar, pendidikan umum dan perguruan tinggi; (2) Pendidikan dan pelatihan dalam jabatan : diklatpim; (3) Masa kerja; (4) Pangkat dan golongan; (5) Jabatan : adalah kedudukan yang menunjukkan tugas, tanggungjawab, wewenang hak seorang pegawai; (6) DP3 meliputi : kesetiaan, prestasi kerja, tanggung jawab, kejujuran, kerjasama dan praktek kepemimpinan; (7) Daftar Urut Kepangkatan (DUK) pegawai yang lebih tinggi kepangkatannya diberi kesempatan lebih dulu untuk menduduki jabatan yang lowong. Sedangkan pengembangan karir berdasarkan Analisa Jabatan melipurti: (1) uraian jabatan kondisi fisik kesehatan, pendidikan, pekerjaan yang dilaksanakan; (2) Spesifikasi jabatan : pendidikan, pengalaman, kemampuan, kualifikasi emosi dan syarat kesehatan.

\section{Pengertian Kinerja}

Menurut George J. Washin Produktifitas mengandung dua konsep utama, yaitu efisiensi dan efektivitas. Efisiensi mengukur tingkat sumber daya, baik manusia, keuangan, maupun alam yang dibutuhkan untuk memenuhi tingkat pelayanan yang dikehendaki, efektivitas mengukur hasil mutu pelayanan yang dicapai.

Sedarmayanti (2001) menyatakan bahwa kinerja adalah: "Suatu sikap mental 
yang selalu mempunyai pandangan bahwa mutu kehidupan hari ini harus lebih baik dari kemarin dan hari esok harus lebih baik dari hari ini".

M.Sinungan (2009) mendefenisikan kinerja sebagai: "Hubungan antara hasil nyata maupun fisik (barang-barang dan jasa) dengan masukan yang sebenarnya". Tunggal (2000) mendefenisikan kinerja sebagai: "Prestasi seseorang pekerja atau sistem operasi dibandingkan dengan sumber daya yang digunakan keluaran dibagi dengan masukan."Menurut Herjanto Kinerja merupakan suatu ukuran yang menyatakan bagaimana baiknya sumber daya diatur dan dimanfaatkan untuk mencapai hasil yang optimal.

\section{Faktor Faktor yang Mempengaruhi Kinerja}

Menurut Pandji Anoraga (2005). Ada 10 faktor yang sangat diinginkan oleh para karyawan untuk meningkatkan kinerja karyawan, yaitu:

1. Pekerjaan yang menarik

2. Upah yang baik

3. Keamanan dan perlindungan dalam pekerjaan

4. Etos kerja

5. Lingkungan atau sarana kerja yang baik

6. Promosi dan perkembangan diri

7. Merasa terlibat dalam kegiatankegiatan organisasi

8. Pengertian dan simpati atas persoalanpersoalan pribadi

9. Kesetiaan pimpinan pada diri sipekerja

10. Disiplin kerja yang keras

\section{METODE PENELITIAN}

\section{Objek Penelitian}

Objek penelitian ini adalah pegawai di Kantor Kesatuan Bangsa Dan Politik Kabupaten Lampung Barat, yang beralamat di Jln.Mawar No.3 Komplek Pemda Liwa Lampung Barat. Penelitian ini di laksanakan dari bulan April sampai dengan Juli 2018.

\section{Metode dan Teknik Pengumpulan Data}

Metode pengumpulan data merupakan cara atau teknik dalam proses pengumpulan data penelitian. Sehubungan dengan jenis penelitian desain kausal.

Untuk mendapatkan dan mengumpulkan data yang sesuai dengan kebutuhan dalam penelitian ini, maka metode pengumpulan data yang digunakan adalah sebagai berikut :

1. Data primer yaitu jenis data yang dikumpulkan dan diolah langsung dari objek penelitian yaitu dari Kantor Kesatuan Bangsa Dan Politik Kabupaten Lampung Barat seperti catatan, agenda, dokumen dan lain-lain.

2. Data Sekunder yaitu data yang bersumber dari luar objek penelitian seperti buku-buku, majalah, yang berkaitan dengan masalah penelitian ini.

Langkah-langkah pengumpulan data yang penulis lakukan dengan mengadakan penelitian lapangan yaitu penelitian yang dilakukan pada Kantor Kesatuan Bangsa Dan Politik Kabupaten Lampung Barat,adapun teknik yang digunakan dalam pengumpulan data adalah dengan :

1. Observasi

Yaitu mengadakan survey atau pengamatan langsung ke lokasi penelitian.

2. Interview atau wawancara Yaitu mengadakan tanya jawab langsung dengan pegawai pada Kantor Kesatuan Bangsa Dan Politik Kabupaten Lampung Barat. 
3. Dokumentasi

Yaitu mengumpulkan dan mencatat dokumentasi yang relevan.

\section{Quisioner}

Yaitu membuat pertanyaan yang berhubungan dengan varibael penelitian.

\section{Sampel dan Populasi}

Sampel penelitian adaalah sebagian dari populasi yang mewakili sifat dan karakter yang sama. Dengan mengambil sampel dimaksudkan untuk menyederhanakan jumlah subjek yang harus diteliti, tetapi hasil penelitian terhadap sampel itu akan digeneralisasikan pada populasi yang ada. Untuk menentukan banyak sampel, peneliti menggunakan pedoman dari pendapat Suharsimi Arikunto (2007) maka apabila subyeknya kurang dari 100, lebih baik diambil semua sehingga penelitiannya merupakan penelitian populasi. Selanjutnya jika jumlah subyeknya besar, dapat diambil 10\% - 15\% atau 20\% - 25\% atau lebih. Dalam penelitian ini merupakan penelitian sampel. Adapun jumlah sampel yang diperoleh adalah seluruh populasi pegawai yang berjumlah 34 orang pegawai Kantor Kesatuan Bangsa Dan Politik Kabupaten Lampung Barat.

\section{Metode Analisis Data}

Analisis kualitatif merupakan analisis yang dinyatakan dalam bentuk uraian dan didasarkan pada data yang telah ada. Data kualitatif merupakan data berupa informasi yang kemudian dikaitkan dengan data lainnya sehingga memunculkan suatu kebenaran. Analisis ini berguna untuk menjelaskan tentang berbagai macam masalah atau hal-hal penting yang dinyatakan dalam bentuk kalimat.

Analisis kuantitatif adalah metode analisis dengan angka-angka yang dapat dihitung maupun diukur, dan dalam prosesnya menggunakan alat bantu statistik. Statistik sendiri merupakan cara-cara ilmiah yang digunakan untuk mengumpulkan, mengolah, menganalisis, dan menginterpretasikan data berupa angkaangka, kemudian menarik kesimpulan atas data tersebut, dimana data tersebut disajikan dalam bentuk tabel, grafik, atau gambar (Algifari, 2008).

Persamaan Regresi Linear

Sederhana menentukan persamaan regresi linear sederhana untuk $\mathrm{X}$ :

$$
Y=a+b X+e
$$

Keterangan:

$$
\begin{aligned}
& \mathrm{Y}=\text { Kinerja } \\
& \mathrm{a}=\text { Konstanta } \\
& \mathrm{b}=\text { Koefisien regresi } \mathrm{X} \\
& \mathrm{X}=\text { Pengembangan karier } \\
& \mathrm{e}=\text { Faktor kesalahan }
\end{aligned}
$$

Untuk mengetahui besarnya pengaruh, penghitungan koefisien korelasi tersebut kemudian dilanjutkan dengan Rumus Koefisien Determinasi atau Koefisien Penentu (KP):

$$
K P=(r)^{2} x 100 \%
$$

Untuk menguji secara hipotesis secara parsial digunakan Uji t dengan rumus :

$$
t_{\text {hitung }}=\frac{r \sqrt{N-2}}{\sqrt{1-r^{2}}}
$$

Keterangan:

$$
\begin{array}{ll}
\mathrm{t}_{\text {hitung }} & =\text { Nilai } \mathrm{t} \\
\mathrm{r} & =\text { Koefisien Korelasi } \\
\mathrm{N} & =\text { Jumlah responden }
\end{array}
$$

Kriteria untuk Uji $\mathrm{t}$ adalah sebagai berikut :

a) Jika $t_{\text {hitung }}>t_{\text {tabel }}$ maka Ha diterima dan Ho ditolak. 
b) Jika $t_{\text {hitung }} \leq \mathrm{t}_{\text {tabel }}$ maka Ha ditolak dan Ho diterima.

\section{HASIL DAN PEMBAHASAN}

\section{Uji Validitas}

Data penelitian yang telah dikumpulkan kemudian diolah untuk menguji kualitas data berupa uji validitas dan reliabilitas. Hasil uji validitas dapat dilihat pada Tabel 1.

Tabel 1. Hasil Uji Validitas Instrumen Variabel Pengembangan karier

\begin{tabular}{lccc}
\hline Indikator & r hitung & r tabel & Keterangan \\
\hline X11 & 0.817 & 0.514 & Valid \\
X12 & 0.869 & 0.514 & Valid \\
X13 & 0.904 & 0.514 & Valid \\
X14 & 0.869 & 0.514 & Valid \\
X15 & 0.837 & 0.514 & Valid \\
\hline
\end{tabular}

Berdasarkan Tabel 1. nilai $\mathrm{r}$ hitung kompensasi lebih besar dari $r$ tabel (0.514), sehingga seluruh indikator dinyatakan valid.

Tabel 2. Hasil Uji Validitas Instrumen Variabel Kinerja

\begin{tabular}{lrcc}
\hline Indikator & r hitung & r tabel & Keterangan \\
\hline Y11 & 0.938 & 0.514 & Valid \\
Y12 & 0.903 & 0.514 & Valid \\
Y13 & 0.860 & 0.514 & Valid \\
Y14 & 0.922 & 0.514 & Valid \\
Y15 & 0.903 & 0.514 & Valid \\
\hline
\end{tabular}

Berdasarkan Tabel 2. hasil perhitungan menunjukkan bahwa seluruh indikator untuk variabel kinerja adalah lebih besar dari $\mathrm{r}$ tabel, sehingga seluruh indikator dinyatakan valid.

\section{Uji Reliabilitas Data}

Nilai reliabilitas konsistensi internal untuk koefisien Alpha Cronbach dinyatakan reliabel karena lebih besar dari 0,60. Dengan demikian item pengukuran pada masing-masing indikator dalam variabel-variabel penelitian dinyatakan reliabel dan selanjutnya dapat digunakan dalam penelitan.

\section{Analisis Kuantitatif}

Persamaan regresi linier sederhana yang diperoleh adalah $\mathrm{Y}=4.063+0.819 \mathrm{X}$. Nilai konstanta yang diperoleh sebesar 4.063, hal ini berarti bahwa jika variabel independen (pengembangan karir) adalah bernilai nol, maka besarnya kinerja yang terjadi adalah 4.06. Nilai koefisien regresi variabel pengembangan karir (X) sebesar 0,819 , hal ini menunjukkan bahwa setiap kenaikan satu satuan pengembangan karir akan mengakibatkan kenaikan kinerja sebesar 0,819 .

Hasil pengujian menunjukkan bahwa nilai $R$ square sebesar 0.670 . Nilai $R$ square ini menunjukkan bahwa besarnya kontribusi variabel independen terhadap variabel dependen adalah sebesar 67,0\%, sedangkan sisanya sebesar 33,0 \% ditentukan oleh variabel lain yang tidak teridentifikasi dalam penelitian ini.

Dari hasil uji kelayakan model dapat dilihat pada nilai signifikansi sebesar 0.00 lebih kecil dari 0.05. Dengan melihat tingkat signifikansi tersebut, maka model ini dapat digunakan untuk memprediksi produktivitas (Y), dengan demikian persamaan model ini bersifat fit atau layak digunakan.

Pengujian hipotesis yang menyatakan "Pengembangan karir berpengaruh terhadap kinerja." Pengujian dilakukan dengan menggunakan uji $t$ yang menunjukkan bahwa Pengembangan karir berpengaruh terhadap kinerja. Pengujian dilakukan dengan menggunakan uji $\mathrm{t}$ pada tingkat keyakinan signifikansi $\alpha 0.05$. Dari hasil tabel 4.8 dapat diketahui bahwa tingkat signifikansi sebesar $0.00<0.05$ dengan nilai $t_{\text {hitung }}>t_{\text {tabel }}$ yaitu $8.063>2.034$, dengan demikian hipotesis diterima yang 
berarti Pengembangan karir berpengaruh terhadap kinerja.

\section{KESIMPULAN DAN SARAN}

\section{Kesimpulan}

Berdasarkan hasil penelitian dan pembahasan dapat disimpulkan bahwa pengujian dilakukan menunjukkan pengembangan karier berpengaruh terhadap kinerja. Pengujian dilakukan dengan menggunakan uji t pada tingkat keyakinan signifikansi $\alpha 0.05$, diketahui bahwa tingkat signifikansi sebesar $0.00<0.05$ dengan nilai $t_{\text {hitung }}>t_{\text {tabel }}$ yaitu $8.063>2.034$, dengan demikian hipotesis diterima yang berarti pengembangan karier berpengaruh terhadap kinerja.

\section{Saran}

Adapun saran yang diajukan peneliti adalah sebagai berikut:

1. Kantor Kesatuan Bangsa dan Politik Kabupaten Lampung Barat hendaknya mempertimbangan pengembangan karier yang diberikan kepada pegawainya agar mereka semakin meningkatkan kinerja.

2. Pimpinan Kantor Kesatuan Bangsa dan Politik Kabupaten Lampung Barat hendaknya memberikan kesempatan kepada pegawainya sesuai dengan kemampuan dan kualitas yang dimiliki sesuai dengan kinerjanya.

\section{DAFTAR PUSTAKA}

Arikunto, Suharsimi. 2010. Prosedur Penelitian. Jakarta: Bina Aksara.

As'ad, Moh. 2004. Psikologi Industri. Yogyakarta: Liberty.
Augusty, Ferdinand. 2006. Metode Penelitian Manajemen. Semarang: Badan Penerbit Universitas Diponegoro.

Effendi, Sofian. 2002 Metode Penelitian dan Survey. Jakarta: Penerbit LP3S.

Filippo, Edwin B. 2006. Manajemen Personalia Jilid I. Diterjemahkan oleh Moh. Masud. Jakarta: Erlangga.

Hamzah B Uno. 2008. Teori Motivasi dan Pengukurannya Analisis di Bidang Pendidikan. Jakarta: Bumi Aksara.

Hasibuan, Malayu S.P. 2000. Manajemen Sumber Daya Manusia. Jakarta: BumiAksara.

Kusnadi. 2002. Teoridan Manajemen Konflik. Malang :Taroda.

Marihot, T.E Hariandja. 2002. Manajemen Sumber Daya Manusia. Jakarta: Grasindo.

Mutiara, S Panggabean. 2002. Manajemen Sumber Daya Manusia. Jakarta: Ghalia Indonesia.

Pandji, Anoraga. 2005. Manajemen Bisnis, Cetakan Ketiga. Jakarta: Rineka Cipta.

R, Wayne Mondy. 2008. Manajemen Sumber Daya Manusia. Jakarta: Erlangga.

Sedarmayanti. 2001. Sumber Daya Manusia dan Produktivitas kerja. Bandung: Mandar Maju.

Siswanto, Sastrohadiwiryo. 2002. Manajemen Tenaga Kerja Indonesia. Jakarta: Bumi Aksara.

Sugiyono. 2008. Metode Penelitian Kunatitatif Kualitatif dan $R \& D$. Bandung: Alfabeta. 